\title{
Relation between surface topography and sea-salt snow chemistry from Princess Elizabeth Land, East Antarctica
}

\author{
K. Mahalinganathan, M. Thamban, C. M. Laluraj, and B. L. Redkar \\ National Centre for Antarctic and Ocean Research, Headland Sada, Vasco da Gama, Goa 403804, India \\ Correspondence to: K. Mahalinganathan (maha@ ncaor.org)
}

Received: 5 October 2011 - Published in The Cryosphere Discuss.: 27 October 2011

Revised: 26 March 2012 - Accepted: 28 March 2012 - Published: 18 April 2012

\begin{abstract}
Previous studies on Antarctic snow have established an unambiguous correlation between variability of sea-salt records and site specific features like elevation and proximity to the sea. On the other hand, variations of $\mathrm{Cl}^{-} / \mathrm{Na}^{+}$ratios in snow have been attributed to the reaction mechanisms involving atmospheric acids. In the present study, the annual records of $\mathrm{Na}^{+}, \mathrm{Cl}^{-}$and $\mathrm{SO}_{4}^{2-}$ were investigated using snow cores along a $180 \mathrm{~km}$ coast to inland transect in Princess Elizabeth Land, East Antarctica. Exceptionally high $\mathrm{Na}^{+}$concentrations and large variations in $\mathrm{Cl}^{-} / \mathrm{Na}^{+}$ratios were observed up to $50 \mathrm{~km}(\sim 1100 \mathrm{~m}$ elevation) of the transect. The steepest slope in the entire transect $\left(49.3 \mathrm{~m} \mathrm{~km}^{-1}\right)$ was between 20 and $30 \mathrm{~km}$ and the sea-salt records in snow from this area revealed extensive modifications, with $\mathrm{Cl}^{-} / \mathrm{Na}^{+}$ratios as low as 0.2 . Statistical analysis showed a strong association between the slope and variations in $\mathrm{Cl}^{-} / \mathrm{Na}^{+}$ratios along the transect $(r=-0.676,99 \%$ confidence level). While distance from the coast accounted for some variability, the altitude by itself has no significant control over the sea-salt ion variability. However, the steep slopes influence the deposition of sea-salt aerosols in snow. The wind redistribution of snow due to the steep slopes on the coastal escarpment increases the concentration of $\mathrm{Na}^{+}$, resulting in a low $\mathrm{Cl}^{-} / \mathrm{Na}^{+}$ratios. We propose that the slope variations in the coastal regions of Antarctica could significantly influence the sea-salt chemistry of snow.
\end{abstract}

\section{Introduction}

Studies on spatial variability of snow chemistry and accumulation provide a unique opportunity to understand the fundamental factors influencing the ice core records. Spatial variations of snow chemistry in Antarctica are mainly attributed to the site-specific features like elevation, distance from the sea and to an extent, snow accumulation (Bertler et al., 2005). The snow accumulation and sea-salt concentrations decrease with respect to increase in elevation and distance from the coast (Giovinetto et al., 1990). A compilation of previously published data from various Antarctic sites shows that the snow chemistry concentrations varied by up to four orders of magnitude with a distinct geographical pattern across Antarctica (Bertler et al., 2005). Studies have also shown the importance of complex morphology of the snow surface (Goodwin, 1990), including micro-relief features (Frezzotti et al., 2005) and the megadune movement (Frezzotti et al., 2002), which play an important role in the snow accumulation in the Antarctic ice sheets. However, very few studies (Kreutz and Mayewski, 1999; Stenberg et al., 1998; Thamban et al., 2010) have attempted to elucidate the role of surface physical features on snow chemistry in Antarctica. A thorough knowledge of all these parameters is critical, for instance, to understand the past compositional changes in deep ice cores.

The major chemical constituents of the Antarctic snow and ice are the sea-salt ions $\left(\mathrm{Na}^{+}, \mathrm{Cl}^{-}, \mathrm{SO}_{4}^{2-}, \mathrm{K}^{+}, \mathrm{Mg}^{2+}\right.$ and $\left.\mathrm{Ca}^{2+}\right)$, the atmospheric acids $\left(\mathrm{H}_{2} \mathrm{SO}_{4}\right.$ and $\left.\mathrm{HNO}_{3}\right)$ along with minor amounts of biologically derived components (MSA, $\mathrm{NH}_{4}^{+}$) and other organic acids (Hall and Wolff, 1998). High concentrations of sea-salt aerosols are common in the coastal margins of Antarctica and have a profound influence on the formation of cloud condensation nuclei. This in turn affects the coastal climate by atmospheric scattering of solar radiation (Murphy et al., 1998). $\mathrm{Cl}^{-}$and $\mathrm{Na}^{+}$constitute the majority of sea-salt aerosols in the coastal Antarctic atmosphere. Sea spray from the ocean surface is considered to 
be a major contributor of sea-salt aerosol in the Antarctic atmosphere (Wagenbach, 1996). On the other hand, enhanced biological activity and sporadic volcanic inputs are considered to be the major sources of atmospheric $\mathrm{H}_{2} \mathrm{SO}_{4}$ (Minikin et al., 1998). During winter, frost flowers on the fresh seaice surface and the precipitation of mirabilite are considered to form a dominant source of sea-salt rather than from the open ocean (Rankin and Wolff, 2002). Measurements of the ionic components in snow and ice show that the ratios among $\mathrm{Cl}^{-}, \mathrm{Na}^{+}$and $\mathrm{SO}_{4}^{2-}$ are modified with respect to the bulk seawater composition (Benassai et al., 2005). Such modifications in $\mathrm{Cl}^{-}$and $\mathrm{Na}^{+}$involve heterogeneous reactions with atmospheric acids like $\mathrm{H}_{2} \mathrm{SO}_{4}$ and $\mathrm{HNO}_{3}$, liberating reactive halogen species (Legrand and Delmas, 1988):

$\mathrm{NaCl}+\mathrm{HNO}_{3} \rightarrow \mathrm{HCl}_{(\mathrm{g})}+\mathrm{NaNO}_{3}$

$2 \mathrm{NaCl}+\mathrm{H}_{2} \mathrm{SO}_{4} \rightarrow 2 \mathrm{HCl}_{(\mathrm{g})}+\mathrm{Na}_{2} \mathrm{SO}_{4}$

Therefore, a significant variation in the $\mathrm{SO}_{4}^{2-}$ and $\mathrm{NO}_{3}^{-}$concentrations observed in snow could partly be explained by the reactions of atmospheric acid with the sea-salt aerosol. $\mathrm{Cl}^{-}$present in the sea-salt aerosol is continually lost to the gas phase in the form of $\mathrm{HCl}$ and changes result in a low average $\mathrm{Cl}^{-} / \mathrm{Na}^{+}$ratio, with respect to the bulk seawater composition. The seasonal pattern arising due to the differences in fractionation of sea-salt is phenomenally used in inferring long-term variability of atmospheric conditions (Aristarain and Delmas, 2002). $\mathrm{Cl}^{-} / \mathrm{Na}^{+}$ratio in snow or ice is compared with that of seawater ratio to understand the chemical processes that occur during the transport and deposition of snow (Legrand and Delmas, 1988). For instance, Hara et al. (2004) showed that the sea-salt particles are transported over long distances to the coastal (Syowa) and inland (Dome Fuji) sites, resulting in $\mathrm{Cl}^{-} / \mathrm{Na}^{+}$ratios closer to the bulk sea water ratio. On the other hand, reduced $\mathrm{Cl}^{-} / \mathrm{Na}^{+}$ratios in the snow have been linked to shorter atmospheric residence times of the sea salt aerosols (Legrand and Delmas, 1988) and post-depositional $\mathrm{HCl}$ losses in surface snow (Wagnon et al., 1999). Reduced $\mathrm{HCl}$ formation in the atmosphere, owing to the higher dust levels, results in a higher $\mathrm{Cl}^{-} / \mathrm{Na}^{+}$ratio at certain periods in the past and has also been reported from an ice core study (Röthlisberger et al., 2008).

Hall and Wolff (1998) have demonstrated the importance of coastal topography in regulating the sea-salt concentrations in Antarctic snow. A coast with mountain ranges, for instance, acts as a barrier for sea-salt laden maritime winds or induces the funnelling effect of katabatic winds around the mountains. The present study investigates the possibility of a relationship between the coastal topography with steep slopes and sea-salt snow chemistry, using high resolution data from snow cores along a coast to inland transect in the Princess Elizabeth Land, East Antarctica.

\section{Sampling and methodology}

Despite having the largest glacier basin in Antarctica, Princess Elizabeth Land is one of the least studied regions in terms of seasonal and spatial variations in snow chemistry. Previous studies in this region indicate that the coastal area is dominated by a steep escarpment zone influenced by katabatic winds (Allison, 1998). On the other hand, the maritime winds in the coastal region constantly blow from the east to northeast direction (Ma et al., 2010). Therefore, prior to the field sampling, adequate planning was made to sample along a transect perpendicular to the elevation contours in order to study the effect of rapid elevation changes and the interacting wind regimes on the chemistry of snow. A RADARSAT Antarctic Mapping Project (RAMP) $5 \mathrm{~km}$ digital elevation map was used while planning the transect (Fig. 1).

Beginning at $10 \mathrm{~km}$ from the coast, a series of one-meter snow cores was collected approximately at $10 \mathrm{~km}$ intervals up to $180 \mathrm{~km}$ with the helicopter support. Snow coring was carried out using a KOVACS Mark IV device with a $14 \mathrm{~cm}$ diameter barrel. This method allowed a faster way of sampling at higher resolution along the transect. Necessary precautions like sterile, long-hand, powder-free rubber gloves, polyethylene gloves and face masks were used during sampling to reduce the risk of contamination. Further, to avoid contamination due to movement of the transect team, sampling was always carried out $\sim 50 \mathrm{~m}$ upwind from the landing site at each location. Twenty-two snow cores were collected along the transect that covered an elevation up to $2200 \mathrm{~m}$. Within the coastal section between 20 and $50 \mathrm{~km}$, cores were collected at closer intervals to assess the spatial variability due to rapid changes in elevation. The cores were directly transferred from the core barrel in to clean custom made HDPE (high density polyethylene) bags, and sealed immediately. The strong wind action in this region ensured compaction of the snow and prevented the possible disintegration of cores. All samples were transported in EPP (Expanded Poly Propylene) boxes and stored at $-20^{\circ} \mathrm{C}$ conditions prior to the laboratory sub-sampling at the National Centre for Antarctic and Ocean Research (Goa, India).

Sub-sampling of snow cores at $5 \mathrm{~cm}$ resolution was carried out under clean conditions in a laminar-flow bench, housed in the processing facility in $\mathrm{a}-15^{\circ} \mathrm{C}$ cold room. All subsampling equipment and sample containers were pre-cleaned by rinsing several times with Milli-Q water (18 M $\Omega$ ), soaking for at least $24 \mathrm{~h}$, followed by rinsing with fresh Milli$\mathrm{Q}$ water and drying in a laminar-flow bench. Samples were melted immediately prior to the analysis in a class 100 clean room facility. Cations $\left(\mathrm{Na}^{+}, \mathrm{NH}_{4}^{+}, \mathrm{K}^{+}, \mathrm{Mg}^{2+}, \mathrm{Ca}^{2+}\right.$ ) were analysed using a Dionex DX-2500 with IonPac CS17 column and anions $\left(\mathrm{Cl}^{-}, \mathrm{MSA}^{-}, \mathrm{SO}_{4}^{2-}\right.$ and $\left.\mathrm{NO}_{3}^{-}\right)$were analysed on a Dionex ICS-2000 with IonPac AS11-HC column. The detection limits were within $2 \mu \mathrm{gl}^{-1}$ for $\mathrm{Cl}^{-}, \mathrm{SO}_{4}^{2-}$ and $\mathrm{Na}^{+}$. Reference standards and random samples were analysed routinely to estimate the analytical precision, which was better 

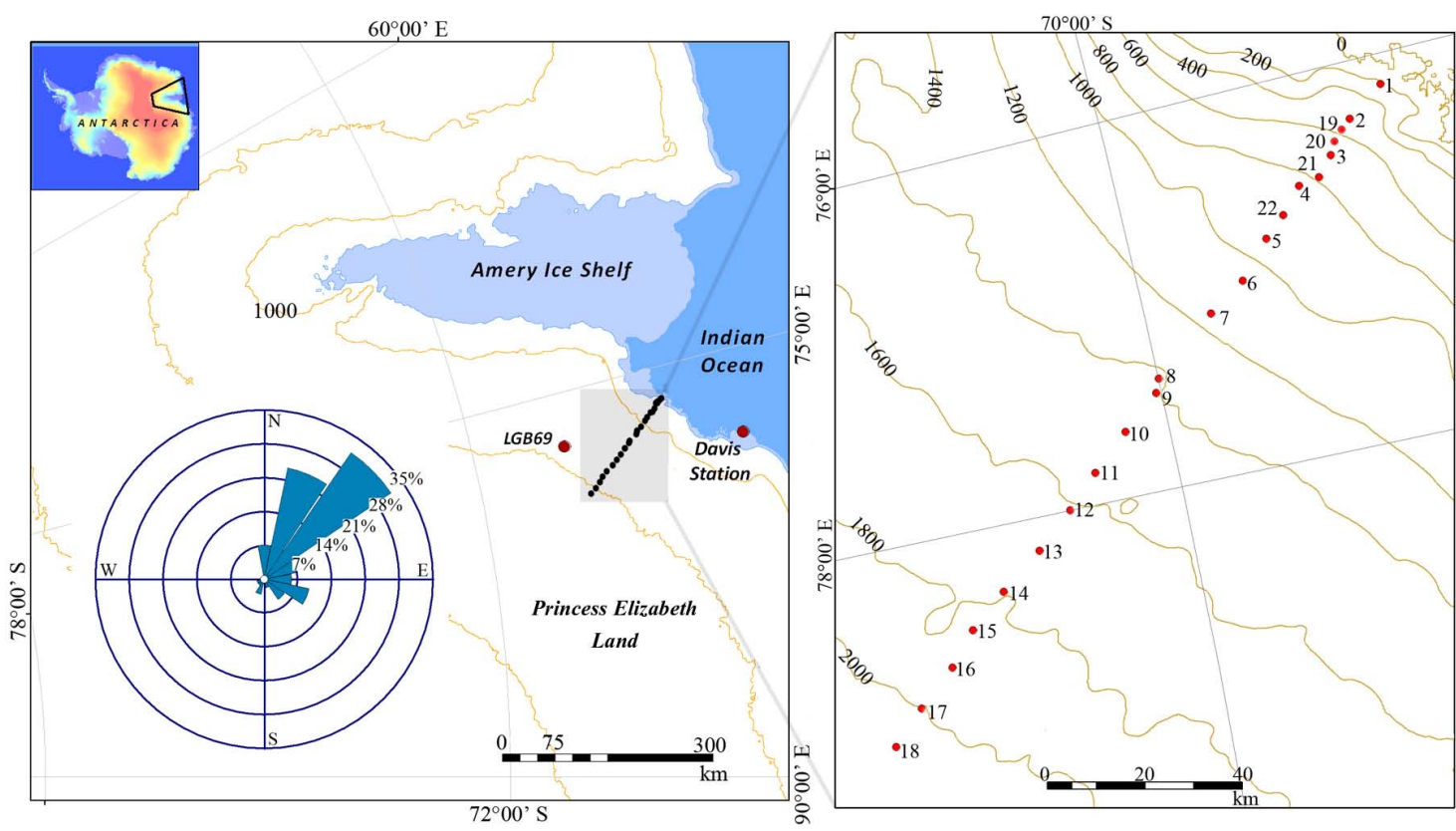

Fig. 1. Map showing the sampling locations in Princess Elizabeth Land transect. Inset on the left corner shows the wind rose chart for 2008, showing prevalent wind direction (NNE-ENE) on the coast.

than $5 \%$ for $\mathrm{SO}_{4}^{2-}, \mathrm{NO}_{3}^{-}$, and MSA. For $\mathrm{Cl}^{-}$, the precision was within $10 \%$. The cations also had a precision better than $5 \%$. Stable isotope ratios were measured using a dual inlet, Isoprime Isotope Ratio Mass Spectrometer, following standard analytical procedures (Naik et al., 2010). The external precision obtained using a laboratory standard (CDML 1) on oxygen isotope analysis was $\pm 0.05 \%$.

\subsection{Determination of seasonality and annual accumulation from snow cores}

$\delta^{18} \mathrm{O}$ values were used to delineate individual years as well as to determine the seasonal sea-salt concentrations in the snow cores along the transect. The snow cores were compact enough (density $\sim 0.4 \mathrm{~g} \mathrm{~cm}^{-3}$ ) to prevent mixing or crushing during transportation. A seasonal $\delta^{18} \mathrm{O}$ amplitude of $4 \%$ o was considered large enough to represent the temperature difference between summer and winter precipitation (Stenberg et al., 1998). The seasonal amplitude of $\delta^{18} \mathrm{O}$ values for snow cores from Princess Elizabeth Land transect was larger than $6 \%$. $\delta^{18} \mathrm{O}$ records were obscured at certain locations, which could be attributed to variations in seasonal amplitude of condensation temperature (Helsen et al., 2005). Annual layers were identified based on the extreme values of $\delta^{18} \mathrm{O}$ between summer and winter (Fig. 2).

\subsection{Determination of slope}

Princess Elizabeth Land showed a marked contrast in elevation changes between the coast and the inland region (Fig. 1). Between $20 \mathrm{~km}$ and $50 \mathrm{~km}$ (from the coast, unless otherwise mentioned), the elevation showed a rapid increase from $300 \mathrm{~m}$ to $1113 \mathrm{~m}$, indicating a steep escarpment zone. Beyond $50 \mathrm{~km}$, the elevation increased gradually (from $1113 \mathrm{~m}$ to $2109 \mathrm{~m}$ ) up to $180 \mathrm{~km}$. In order to estimate the slope between subsequent sampling points, a combination of elevation data and the distance from the coast along the transect were used. Accordingly, the slope was calculated as elevation change/distance change (between two points). Slope values were subsequently derived in terms of $\mathrm{m} \mathrm{km}^{-1}$. The slope variations between the coast and inland region were also prominent. The coastal escarpment zone (between $20 \mathrm{~km}$ and $50 \mathrm{~km}$ ) showed an average slope of $27.1 \mathrm{~m} \mathrm{~km}^{-1}$. The steepest region was located between $20 \mathrm{~km}$ and $30 \mathrm{~km}$, with a slope of $49.3 \mathrm{~m} \mathrm{~km}^{-1}$. However, the interior region between $50 \mathrm{~km}$ and $100 \mathrm{~km}$ showed a threefold decrease in slope $\left(9.4 \mathrm{~m} \mathrm{~km}^{-1}\right)$. Further interior, the slope reduced $\left(7.8 \mathrm{~m} \mathrm{~km}^{-1}\right)$ between $100 \mathrm{~km}$ and $180 \mathrm{~km}$ (Fig. 5, inset).

\section{Results}

The snow accumulation rates showed large variations, ranging between $138 \mathrm{~kg} \mathrm{~m}^{-2} \mathrm{yr}^{-1}$ in the inland $(120 \mathrm{~km})$ and $389 \mathrm{~kg} \mathrm{~m}^{-2} \mathrm{yr}^{-1}$ closer to the coast $(30 \mathrm{~km})$ (Table 1). The steepest section (with a slope of $49.3 \mathrm{~m} \mathrm{~km}^{-1}$ ) showed largest variability with accumulation rates ranging between 155 and $389 \mathrm{~kg} \mathrm{~m}^{-2} \mathrm{yr}^{-1}$ (at 23 and $30 \mathrm{~km}$, respectively). With an exception of this low accumulation rate at $23 \mathrm{~km}$, the escarpment region (with a slope of $27.1 \mathrm{~m} \mathrm{~km}^{-1}$ ) up to $50 \mathrm{~km}$ showed an average snow accumulation rate of $293 \mathrm{~kg} \mathrm{~m}^{-2} \mathrm{yr}^{-1}$. The section between 50 and $100 \mathrm{~km}$ 

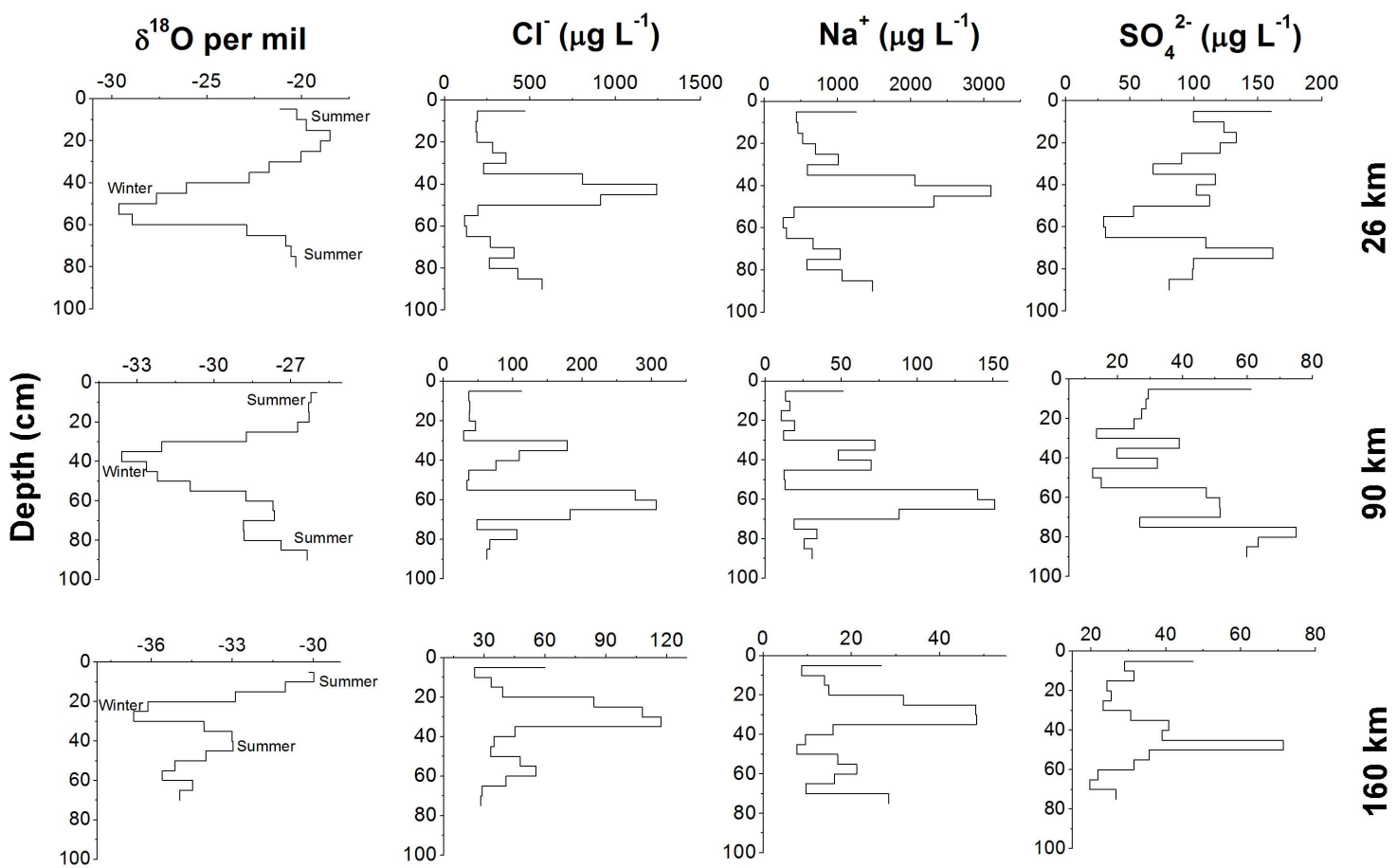

Fig. 2. Temporal records of $\delta^{18} \mathrm{O}, \mathrm{Cl}^{-}, \mathrm{Na}^{+}$and $\mathrm{SO}_{4}^{2-}$ from sites representing coast $(26 \mathrm{~km})$, mid-way $(90 \mathrm{~km})$ and the interior $(160 \mathrm{~km})$ in Princess Elizabeth Land. Seasonality in $\delta^{18} \mathrm{O}$ variability was primarily used to determine the annual accumulations within the core, supported by $\mathrm{Na}^{+}, \mathrm{Cl}^{-}$and $\mathrm{SO}_{4}^{2-}$ records.

(average slope of $9.4 \mathrm{~m} \mathrm{~km}^{-1}$ ) showed an average accumulation rate of $\sim 300 \mathrm{~kg} \mathrm{~m}^{-2} \mathrm{yr}^{-1}$. The interior section (average slope of $7.8 \mathrm{~m} \mathrm{~km}^{-1}$ ) beyond showed an average snow accumulation of $\sim 270 \mathrm{~kg} \mathrm{~m}^{-2} \mathrm{yr}^{-1}$ (Table 1).

$\mathrm{Na}^{+}, \mathrm{Cl}^{-}$and $\mathrm{SO}_{4}^{2-}$ showed a wide range in concentration from the coast to inland (Fig. 3a). Concentrations of $\mathrm{Na}^{+}$and $\mathrm{Cl}^{-}$were always higher in the initial $30 \mathrm{~km}$ of the transect, exceeding $100 \mu \mathrm{g}^{-1}$ throughout the year (Fig. 3a). Besides, exceptionally high $\mathrm{Na}^{+}$concentrations, ranging between 500 and $1500 \mu \mathrm{g} \mathrm{l}^{-1}$, were measured in snow from the steep coastal sections (Fig. 3a). $\mathrm{Cl}^{-}$concentrations did not show a similar trend in the steep zone and ranged between 100 and $1000 \mu \mathrm{g}^{-1}$, effectively lesser than that of $\mathrm{Na}^{+}$. Outliers indicating sporadic events were also present at all the sampling locations, with a maximum $\mathrm{Na}^{+}$input of about $3000 \mu \mathrm{g}^{-1}$ between $20 \mathrm{~km}$ and $30 \mathrm{~km}$. Concentrations declined logarithmically beyond $50 \mathrm{~km}$, with $\mathrm{Na}^{+}$concentration ranging between 10 and $100 \mu \mathrm{gl}^{-1}$ and $\mathrm{Cl}^{-}$between 20 and $200 \mu \mathrm{gl}^{-1}$. $\mathrm{SO}_{4}^{2-}$ showed a background concentration of $25 \mu \mathrm{g} \mathrm{l}^{-1}$ throughout the transect with variations up to $250 \mu \mathrm{g} \mathrm{l}^{-1}$ within $50 \mathrm{~km}$ from the coast. Beyond $50 \mathrm{~km}$, only little variations were observed with concentrations below $75 \mu \mathrm{g} \mathrm{l}^{-1}$ (Fig. 3a).

Seasonal differences in concentrations of $\mathrm{Na}^{+}, \mathrm{Cl}^{-}$and $\mathrm{SO}_{4}^{2-}$ showed large variations in the initial $50 \mathrm{~km}$ of the transect (Fig. 3b). The annual $\mathrm{Cl}^{-}$concentrations always exceeded $\mathrm{Na}^{+}$during the summer and winter throughout the transect, except in the steep zones, where the annual $\mathrm{Na}^{+}$was higher (Fig. 3b). The variations beyond $50 \mathrm{~km}$ were minimal for the $\mathrm{Na}^{+}$and $\mathrm{Cl}^{-}$ions, with average annual concentrations ranging well below $150 \mu \mathrm{gl}^{-1}$. Seasonal $\mathrm{SO}_{4}^{2-}$ concentrations rarely exceeded $200 \mu \mathrm{g} \mathrm{l}^{-1}$, with higher concentrations $\left(\sim 150 \mu \mathrm{g}^{-1}\right)$ during summer near the coasts. The winter averages of $\mathrm{Cl}^{-}$at $23 \mathrm{~km}, 26 \mathrm{~km}$ and $45 \mathrm{~km}(396,519$ and $\left.193 \mu \mathrm{gl}^{-1}\right)$ were lower than that of the $\mathrm{Na}^{+}(502,1275$ and $\left.439 \mathrm{\mu g}^{-1}\right)$. Similarly, the summer averages of $\mathrm{Cl}^{-}$at these locations $\left(270,339\right.$ and $\left.56 \mu \mathrm{g} \mathrm{l}^{-1}\right)$ were lower than that of $\mathrm{Na}^{+}\left(1211,878\right.$ and $\left.102 \mu \mathrm{g} \mathrm{l}^{-1}\right)$. At $30 \mathrm{~km}$, the summer and winter concentrations of both $\mathrm{Na}^{+}$and $\mathrm{Cl}^{-}$were similar ( $\sim 152 \mu \mathrm{g}^{-1}$ in summer, $\sim 603 \mu \mathrm{g} \mathrm{l^{-1 }}$ in winter).

Annual $\mathrm{Cl}^{-} / \mathrm{Na}^{+}$ratios were calculated from all the locations, which averaged slightly lower (1.4) when compared to that of the bulk sea water $(1.81 \mathrm{w} / \mathrm{w})$. However, data from the steepest part of the transect (within $50 \mathrm{~km}$ from the coast) revealed extremely low average annual $\mathrm{Cl}^{-} / \mathrm{Na}^{+}$ratios (Fig. 4a). The lowest average $(0.26)$ was recorded from a site at $26 \mathrm{~km}$, at an elevation of $640 \mathrm{~m}$, followed by 0.33 at $23 \mathrm{~km}$ at an elevation of $580 \mathrm{~m}$. The annual $\mathrm{Cl}^{-} / \mathrm{Na}^{+}$ratios gradually increased from 0.33 at $23 \mathrm{~km}$ to 1.28 at $40 \mathrm{~km}$ inland before reducing to 0.38 at $45 \mathrm{~km}$ inland. Beyond $60 \mathrm{~km}$ the annual $\mathrm{Cl}^{-} / \mathrm{Na}^{+}$ranged between 1.05 and 2.5 , averaging closer (1.73) to that of the bulk sea water ratio (Fig. 4a). 
Table 1. Details of sampling parameters along with slope, accumulation rates and annual $\mathrm{Cl}^{-} / \mathrm{Na}^{+}$values.

\begin{tabular}{|c|c|c|c|c|c|c|c|c|}
\hline Station & $\begin{array}{l}\text { Sampling } \\
\text { Date }\end{array}$ & $\begin{array}{c}\text { Latitude } \\
\text { (S) }\end{array}$ & $\begin{array}{l}\text { Longitude } \\
\text { (E) }\end{array}$ & $\begin{array}{l}\text { Elevation } \\
\text { (m) }\end{array}$ & $\begin{array}{l}\text { Distance } \\
\text { from sea } \\
\quad(\mathrm{km})\end{array}$ & $\begin{array}{c}\text { Slope } \\
\left(\mathrm{m} \mathrm{km}^{-1}\right)\end{array}$ & $\begin{array}{l}\text { Accumulation } \\
\text { rate } \\
\left(\mathrm{kg} \mathrm{m}^{-2} \mathrm{yr}^{-1}\right)\end{array}$ & $\begin{array}{r}\text { Annual } \\
\mathrm{Cl}^{-} / \mathrm{Na}^{+}\end{array}$ \\
\hline 1 & $22 \operatorname{Jan} 2010$ & $69^{\circ} 29^{\prime}$ & $76^{\circ} 10^{\prime}$ & 267 & 10 & 26.77 & n.a & n.a \\
\hline 2 & 22 Jan 2010 & $69^{\circ} 33^{\prime}$ & $76^{\circ} 18^{\prime}$ & 300 & 20 & 3.33 & 227 & 1.39 \\
\hline 3 & 22 Jan 2010 & $69^{\circ} 36^{\prime}$ & $76^{\circ} 28^{\prime}$ & 792 & 30 & 49.32 & 389 & 0.65 \\
\hline 4 & 22 Jan 2010 & $69^{\circ} 40^{\prime}$ & $76^{\circ} 35^{\prime}$ & 975 & 40 & 18.33 & 329 & 1.28 \\
\hline 5 & 22 Jan 2010 & $69^{\circ} 45^{\prime}$ & $76^{\circ} 49^{\prime}$ & 1113 & 50 & 13.75 & 347 & 1.69 \\
\hline 6 & 22 Jan 2010 & $69^{\circ} 49^{\prime}$ & $77^{\circ} 00^{\prime}$ & 1234 & 60 & 12.22 & 270 & 1.05 \\
\hline 7 & 22 Jan 2010 & $69^{\circ} 53^{\prime}$ & $77^{\circ} 08^{\prime}$ & 1280 & 70 & 4.57 & n.a & n.a \\
\hline 8 & 22 Jan 2010 & $70^{\circ} 00^{\prime}$ & $77^{\circ} 25^{\prime}$ & 1494 & 87 & 12.59 & 376 & 1.71 \\
\hline 9 & 22 Jan 2010 & $70^{\circ} 01^{\prime}$ & $77^{\circ} 29^{\prime}$ & 1509 & 90 & 5.09 & 335 & 1.54 \\
\hline 10 & 22 Jan 2010 & $70^{\circ} 05^{\prime}$ & $77^{\circ} 39^{\prime}$ & 1585 & 100 & 7.64 & n.a & n.a \\
\hline 11 & 27 Jan 2010 & $70^{\circ} 09^{\prime}$ & $77^{\circ} 50^{\prime}$ & 1631 & 110 & 4.58 & 256 & 2.54 \\
\hline 12 & 27 Jan 2010 & $70^{\circ} 13^{\prime}$ & $78^{\circ} 00^{\prime}$ & 1722 & 120 & 9.17 & 138 & 1.8 \\
\hline 13 & 27 Jan 2010 & $70^{\circ} 17^{\prime}$ & $78^{\circ} 11^{\prime}$ & 1768 & 130 & 4.58 & 249 & 1.84 \\
\hline 14 & 27 Jan 2010 & $70^{\circ} 22^{\prime}$ & $78^{\circ} 22^{\prime}$ & 1875 & 140 & 10.70 & 179 & 1.76 \\
\hline 15 & 27 Jan 2010 & $70^{\circ} 26^{\prime}$ & $78^{\circ} 32^{\prime}$ & 1920 & 150 & 4.58 & 335 & 1.68 \\
\hline 16 & 27 Jan 2010 & $70^{\circ} 29^{\prime}$ & $78^{\circ} 43^{\prime}$ & 1987 & 160 & 6.72 & 225 & 1.73 \\
\hline 17 & 27 Jan 2010 & $70^{\circ} 33^{\prime}$ & $78^{\circ} 54^{\prime}$ & 2118 & 170 & 13.14 & 246 & 1.83 \\
\hline 18 & 27 Jan 2010 & $70^{\circ} 37^{\prime}$ & $79^{\circ} 05^{\prime}$ & 2210 & 180 & 9.17 & 263 & 2.05 \\
\hline 19 & 02 Feb 2010 & $69^{\circ} 33^{\prime}$ & $76^{\circ} 15^{\prime}$ & 580 & 23 & 28.05 & 155 & 0.33 \\
\hline 20 & 02 Feb 2010 & $69^{\circ} 34^{\prime}$ & $76^{\circ} 17^{\prime}$ & 640 & 26 & 6.02 & 268 & 0.26 \\
\hline 21 & 02 Feb 2010 & $69^{\circ} 38^{\prime}$ & $76^{\circ} 34^{\prime}$ & 884 & 35 & 9.07 & 199 & 1.16 \\
\hline 22 & 02 Feb 2010 & $69^{\circ} 43^{\prime}$ & $76^{\circ} 43^{\prime}$ & 1036 & 45 & 6.08 & 292 & 0.38 \\
\hline
\end{tabular}

n.a. denotes non availability of annual records due to the shorter cores $(<60 \mathrm{~cm})$ due to field constraints.

a)

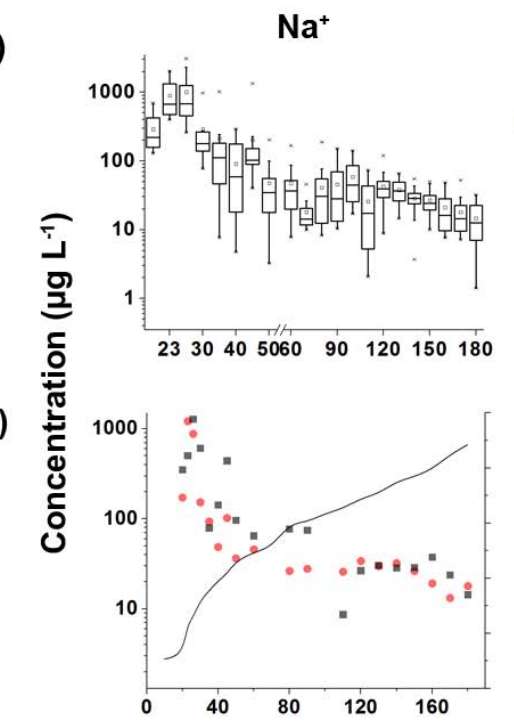

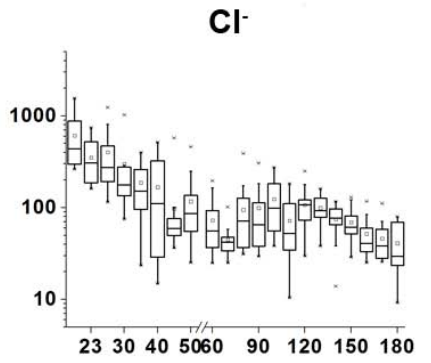
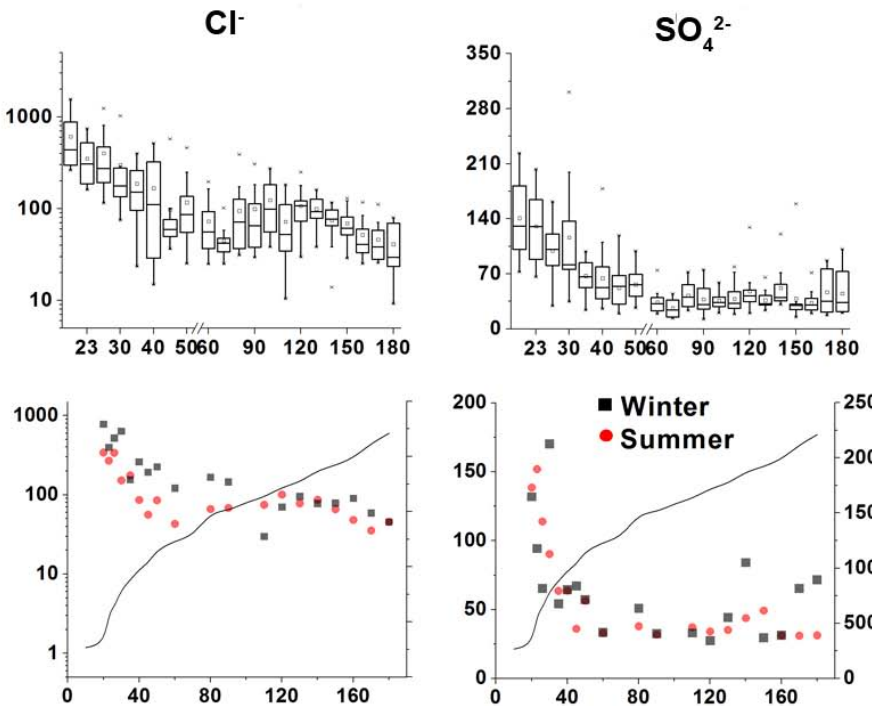

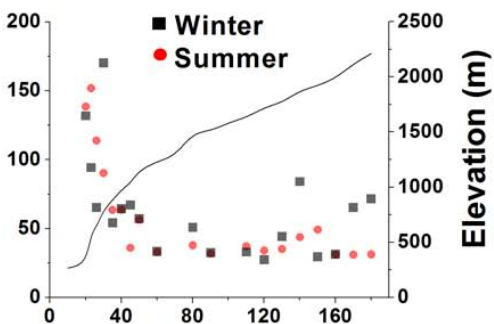

\section{Distance from coast $(\mathrm{km})$}

Fig. 3. (a) Spatial distribution and statistical variations in the annual concentrations of $\mathrm{Na}^{+}, \mathrm{Cl}^{-}$and $\mathrm{SO}_{4}^{2-}$ from coast to inland. Note the logarithmic scale for concentrations in $\mathrm{Na}^{+}$and $\mathrm{Cl}^{-}$plots. The square and the line inside the box represent mean and median, respectively; the whiskers outside the box represent the upper (99\%) and lower (1\%) quartiles and "x" denotes the outliers. Breaks in the $\mathrm{x}$-axis show difference in sampling interval before and after $50 \mathrm{~km}$. (b) The summer and winter concentrations of the respective sea-salt ions along with the elevation profile. 


\section{Discussion}

\subsection{Altitudinal influence on snow chemistry}

Large changes in the elevation distinguished the coastal section from the rest of the transect with the altitude increasing from mean sea level to $\sim 1100 \mathrm{~m}$ within $50 \mathrm{~km}$ from the coast (Fig. 1). However, the concentrations were always higher than $100 \mu \mathrm{gl}^{-1}$ for both $\mathrm{Na}^{+}$and $\mathrm{Cl}^{-}$up to $50 \mathrm{~km}$, and decreased logarithmically thereafter (i.e. $>1100 \mathrm{~m}$ altitude). The steepest zone of the escarpment was between $20 \mathrm{~km}$ and $30 \mathrm{~km}$. Despite the differences in altitude between these locations ( $300 \mathrm{~m}$ and $795 \mathrm{~m}$ ), the concentrations of $\mathrm{Na}^{+}$exceeded an average of $500 \mu \mathrm{gl}^{-1}$ throughout the year (Fig. 3a). $\mathrm{Cl}^{-}$ and $\mathrm{SO}_{4}^{2-}$, on the other hand, did not show a similar trend in concentrations, resulting in high $\mathrm{Na}^{+}$concentration at specific sites within $1000 \mathrm{~m}$ altitude (Fig. 3a).

Previous studies have strongly correlated sea-salt chemistry variations with distance from the sea and elevation in Antarctica (Bertler et al., 2005). Correlation statistics from the present study revealed a strong negative correlation ( $>-0.83,99 \%$ confidence level) between the sea-salt ions and elevation (Table 3). Elevation showed a strong positive correlation $(0.965,99 \%$ confidence level) with distance from the coast. A strong positive correlation existed between the sea-salt ion concentrations and slope $(0.791,99 \%$ confidence level for $\mathrm{Cl}^{-} ; 0.951,99 \%$ confidence level for $\mathrm{Na}^{+}$). A strong negative correlation also existed between slope and $\mathrm{Cl}^{-} / \mathrm{Na}^{+}$ratio $(-0.679,99 \%$ confidence level), a fact that has escaped the attention of previous glaciological studies in Antarctica.

To assess the spatial variations in snow composition from the coastal regions, where the marine influence is greater, it is necessary to determine the individual effects of altitude, distance from the coast as well as the slope variations on snow chemistry. It is clear from Fig. 3 that despite the rapid changes in elevation of $\sim 1100 \mathrm{~m}$, the ion concentrations were always higher than $100 \mu \mathrm{gl} l^{-1}$ for $\mathrm{Na}^{+}$ and $\mathrm{Cl}^{-}$. Previous glaciological studies at higher altitudes of peninsular Antarctica showed that concentrations could reach higher orders because of the influence of the marine air mass (Bertler et al., 2005). For instance, maximum concentrations of 350 and $240 \mu \mathrm{gl}^{-1}$ for $\mathrm{Na}^{+}$and $\mathrm{Cl}^{-}$were measured in the ice cores from James Ross Island, at altitudes $>1500 \mathrm{~m}$ due to the closeness to the sea (Aristarain and Delmas, 2002). To further determine the influence of altitude on sea-salt snow chemistry in the present study, multiple regression was carried out with slope, distance from the sea and elevation as variables affecting the $\mathrm{Cl}^{-} / \mathrm{Na}^{+}$ratio (Table 4). Results revealed that only about $41 \%$ of variation in $\mathrm{Cl}^{-} / \mathrm{Na}^{+}$ratio attributed to the combining effects of elevation and distance from the coast, whereas $62 \%$ of variation occurred due to combining effect of slope and distance from the coast. Therefore, very high concentrations of $\mathrm{Na}^{+}$and $\mathrm{Cl}^{-}\left(>1000 \mu \mathrm{g} \mathrm{l}^{-1}\right)$ in the coastal section $(\sim 1100 \mathrm{~m}$ altitude $)$ could be attributed to the influence of sea-salt rich marine air-mass. Altitudinal variations by itself may not have an important role in the sea-salt concentrations in the snow, at least in the coastal sections where the marine influence is strong. However, the spatial variations of sea-salt chemistry in snow from these steep slopes could be attributed to the highly varying slopes in the present study region.

\section{2 $\mathrm{Cl}^{-}$and $\mathrm{Na}^{+}$variability in the coastal region}

As a result of large variations in sea-salt concentrations up to $\sim 1000 \mathrm{~m}$ altitude, the $\mathrm{Cl}^{-} / \mathrm{Na}^{+}$ratio in snow reduced significantly with respect to the bulk sea water ratio. Previous studies on East Antarctic snow have shown that post-depositional loss of $\mathrm{Cl}^{-}$from snow pack in the form of $\mathrm{HCl}$ could result in a reduced $\mathrm{Cl}^{-} / \mathrm{Na}^{+}$ratio (Wagnon et al., 1999). However, Traversi et al. (2004) suggested that post-depositional loss of $\mathrm{HCl}$ by the above means is strongly dependent on snow accumulation rates. Röthlisberger et al. (2003) showed that the post-depositional loss of $\mathrm{HCl}$ in snow becomes significant only below a threshold accumulation rate of $40 \mathrm{~kg} \mathrm{~m}^{-2} \mathrm{yr}^{-1}$. Also, Benassai et al. (2005) have reported a threshold of $80 \mathrm{~kg} \mathrm{~m}^{-2} \mathrm{yr}^{-1}$ from another East Antarctic site. The snow accumulation rates in the present study ranged between 135 and $389 \mathrm{~kg} \mathrm{~m}^{-2} \mathrm{yr}^{-1}$, well above these threshold limits, suggesting a negligible post-depositional loss of $\mathrm{HCl}$ from the snow pack.

Chloride depletion also occurs by the reaction between atmospheric acids and sea-salt aerosols, leading to the formation of $\mathrm{HCl}$ in the gas phase, thereby lowering $\mathrm{Cl}^{-} / \mathrm{Na}^{+}$ ratios in snow (Legrand and Delmas, 1984). The values of $\mathrm{Cl}^{-} / \mathrm{Na}^{+}$ratios thus depend on the availability of atmospheric acids during different seasons. A few studies with year-round measurements of sea-salt aerosols have shown that $\mathrm{Cl}^{-}$depletion occurs predominantly during the summer months in coastal Antarctica (Kerminen et al., 2000; Jourdain and Legrand, 2002). The chloride depletion is less significant in winter, owing to the reduced atmospheric acidity at this time (Jourdain and Legrand, 2002). The seasonal variations of $\mathrm{Cl}^{-} / \mathrm{Na}^{+}$from bulk aerosol studies suggest that $\mathrm{Cl}^{-}$ depletion takes place during the months of November and December (Jourdain and Legrand, 2002), when higher atmospheric $\mathrm{H}_{2} \mathrm{SO}_{4}$ concentrations scavenge the sea-salt aerosols. In the present study, the lowest $\mathrm{Cl}^{-} / \mathrm{Na}^{+}$values occurred specifically within $50 \mathrm{~km}$ in the zone of steep coastal escarpment (Fig. 4). The steepest slope $\left(49.2 \mathrm{~m} \mathrm{~km}^{-1}\right)$ was observed between $20 \mathrm{~km}$ and $30 \mathrm{~km}$ and the snow samples from this section showed the strongest depletion in $\mathrm{Cl}^{-}$. Seasonal averages revealed a relatively lower $\mathrm{Cl}^{-}$concentration than $\mathrm{Na}^{+}$during summer (Table 2). This pattern continued consistently even in the winter concentrations, resulting in low $\mathrm{Cl}^{-} / \mathrm{Na}^{+}$ratios throughout the year. This suggests that the sea-salt modifications in the coastal sections of Antarctic snow are more likely dependent on an invariable physical feature like the coastal escarpment. 
a)

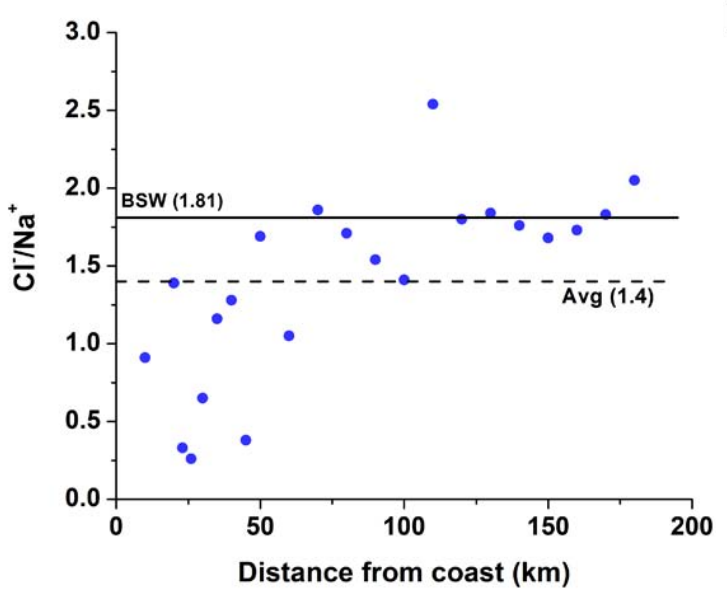

b)

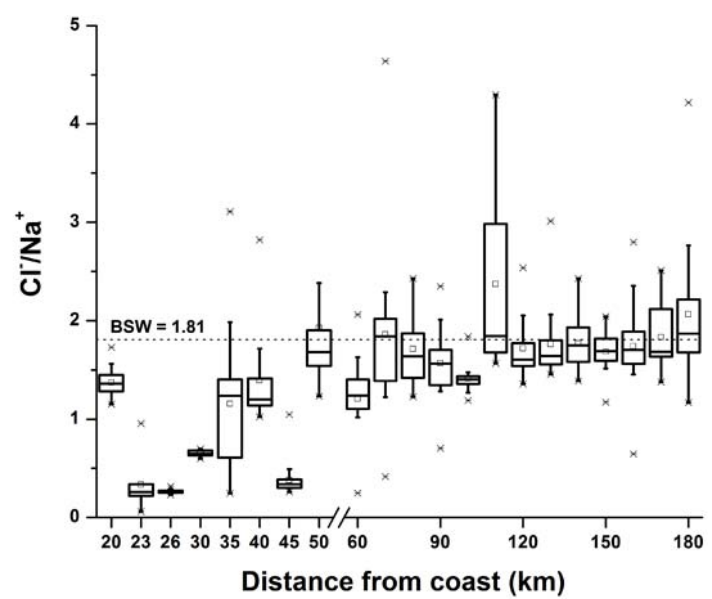

Fig. 4. (a) Average annual $\mathrm{Cl}^{-} / \mathrm{Na}^{+}$ratios from coast to inland. The dashed line is the annual average $\mathrm{Cl}^{-} / \mathrm{Na}^{+}$ratio along the entire transect and the solid line is bulk sea water (BSW) ratio. (b) Seasonal variability in $\mathrm{Cl}^{-} / \mathrm{Na}^{+}$ratios from the entire transect. Please note the break in scale along the $\mathrm{x}$-axis.

Table 2. Seasonal and annual average concentrations of $\mathrm{Na}^{+}, \mathrm{Cl}^{-}$and $\mathrm{SO}_{4}^{2-}$ in snow from the steep escarpment of the transect.

\begin{tabular}{|c|c|c|c|c|c|c|c|c|c|}
\hline \multirow{2}{*}{$\begin{array}{l}\text { Distance } \\
(\mathrm{km})\end{array}$} & \multicolumn{3}{|c|}{$\mathrm{Na}^{+}\left(\mu \mathrm{gl}^{-1}\right)$} & \multicolumn{3}{|c|}{$\mathrm{Cl}^{-}\left(\mu \mathrm{g} 1^{-1}\right)$} & \multicolumn{3}{|c|}{$\mathrm{SO}_{4}^{2-}\left(\mu \mathrm{g} \mathrm{1^{-1 }}\right)$} \\
\hline & Summer & Winter & Annual & Summer & Winter & Annual & Summer & Winter & Annual \\
\hline 20 & 172.45 & 349.32 & 285.01 & 342.28 & 778.70 & 620.00 & 138.67 & 131.99 & 134.42 \\
\hline 23 & 1211.37 & 502.21 & 899.26 & 269.80 & 396.12 & 350.98 & 151.99 & 94.42 & 130.46 \\
\hline 26 & 877.88 & 1275.35 & 1030.75 & 339.02 & 519.28 & 408.35 & 114.03 & 65.45 & 95.34 \\
\hline 30 & 152.82 & 606.41 & 304.02 & 152.37 & 634.37 & 313.04 & 90.43 & 170.25 & 117.04 \\
\hline 35 & 93.42 & 79.25 & 91.55 & 176.40 & 155.40 & 175.55 & 63.73 & 54.36 & 61.78 \\
\hline 40 & 48.65 & 142.51 & 99.28 & 86.31 & 260.07 & 181.49 & 63.92 & 64.64 & 62.48 \\
\hline 45 & 101.93 & 439.80 & 228.63 & 56.34 & 192.85 & 107.53 & 36.26 & 67.29 & 47.89 \\
\hline 50 & 36.37 & 95.96 & 54.04 & 85.58 & 226.18 & 128.14 & 56.55 & 57.28 & 57.43 \\
\hline
\end{tabular}

In addition to the sea-spray, the main factor influencing the $\mathrm{Na}^{+}$in snow is the input of non-sea-salt $\mathrm{Na}^{+}\left(\mathrm{nssNa}^{+}\right)$fraction from the ice-free coasts, exposed nunataks or crustal dust transported over long ranges from other continents. $\mathrm{Na}^{+}$in snow is not known to undergo any post-depositional changes and therefore considered as a conservative species. However, larger input of $\mathrm{nssNa}^{+}$tends to increase the total $\mathrm{Na}^{+}$content in the snow, thereby lowering the $\mathrm{Cl}^{-} / \mathrm{Na}^{+}$ratio with respect to the bulk seawater ratio. Snow samples from the steeper parts of the coasts in the present study showed a relatively higher $\mathrm{Na}^{+}$content than $\mathrm{Cl}^{-}$, indicating a possible $\mathrm{Na}^{+}$enrichment. The sea-salt $\mathrm{Na}^{+}$content in the snow was obtained by subtracting the crustal contribution from the total $\mathrm{Na}^{+}$concentration, calculated on the basis of $\mathrm{Ca}^{2+}$ concentration in snow. Results revealed that the majority of the $\mathrm{Na}+$ content (>85\%) in the coastal snow was of marine origin. A per-sample basis statistical evaluation of snow concentration from the steep slopes showed a strong positive correlation $\left(0.86,99 \%\right.$ confidence level) between $\mathrm{Na}^{+}$and $\mathrm{Cl}^{-}$, indicating the common sea-salt source for these ions. Also, no sources of crustal sodium $\left(\mathrm{nssNa}^{+}\right)$were present in the vicinity of the transect that could significantly contribute to the $\mathrm{Na}^{+}$concentration in snow. A significant positive correlation $(0.590,95 \%$ confidence level) indicates a possible relation between the $\mathrm{Na}^{+}$concentration and slope along the transect. It is more likely that the $\mathrm{Na}^{+}$in snow is redistributed on the steep coastal slopes, possibly during wind scouring, resulting in a high concentration.

\subsection{Influence of slope on snow chemistry}

In order to better understand the sea-salt modification processes in the present study, a distance versus elevation plot was sectioned into three distinct zones based on the average slope and the modification of sea-salt composition in snow (Fig. 5). Considering that the dominant $\mathrm{Cl}^{-}$liberation processes are related to the interaction of sea-salt with the atmospheric $\mathrm{H}_{2} \mathrm{SO}_{4}$ and $\mathrm{Na}-\mathrm{Cl}-\mathrm{SO}_{4}$, ternary plots with composition of snow samples from the transect are presented from the respective zones with reference to the seawater (S), frost flower (F) and mirabilite (M) compositions (Fig. 5). 
Table 3. Correlation coefficients $(r)$ between the site specific features and $\mathrm{Na}^{+}$and $\mathrm{Cl}^{-}$ions. Correlations are based on annual ion concentration data. Values marked with ${ }^{\mathrm{a}}$ and ${ }^{\mathrm{b}}$ represent correlations that are significant at $95 \%$ and $99 \%$ respectively.

\begin{tabular}{lcccccc}
\hline & Distance from sea & Elevation & Slope & $\mathrm{Cl}^{-}$ & $\mathrm{Na}^{+}$ & $\mathrm{Cl}^{-}: \mathrm{Na}^{+}$ \\
\hline Distance from sea & 1 & $0.963^{\mathrm{b}}$ & $-0.468^{\mathrm{a}}$ & $-0.679^{\mathrm{b}}$ & $-0.721^{\mathrm{b}}$ & $0.642^{\mathrm{b}}$ \\
Elevation & & 1 & -0.452 & $-0.841^{\mathrm{b}}$ & $-0.833^{\mathrm{b}}$ & $0.629^{\mathrm{a}}$ \\
Slope & & & 1 & 0.212 & $0.590^{\mathrm{a}}$ & $-0.676^{\mathrm{b}}$ \\
$\mathrm{Cl}^{-}$ & & & & 1 & $0.902^{\mathrm{b}}$ & -0.468 \\
$\mathrm{Na}^{+}$ & & & & & $-0.686^{\mathrm{a}}$ \\
$\mathrm{Cl}^{-}: \mathrm{Na}^{+}$ & & & & & 1 \\
\hline
\end{tabular}

Table 4. Multiple regression model summaries explaining the percentage of $\mathrm{Cl}^{-} / \mathrm{Na}^{+}$variability attributed to the physical parameters. Model 1 shows the variance due to slope entered in the regression equation followed by distance from sea and elevation while model 2 shows the variation due to elevation, followed by distance from sea and slope.

\begin{tabular}{llrr}
\hline \multirow{2}{*}{ Model } & \multicolumn{2}{c}{$\mathrm{Cl}^{-}: \mathrm{Na}^{+}$} \\
\cline { 3 - 3 } & & $R$ & Variance (\%) \\
\hline 1 & Slope & 0.685 & 47.0 \\
& Slope, distance from sea & 0.787 & 62.0 \\
& Slope, distance from sea, elevation & 0.796 & 63.3 \\
2 & Elevation & 0.629 & 39.6 \\
& Elevation, distance from sea & 0.643 & 41.3 \\
& Elevation, distance from sea, slope & 0.796 & 63.3 \\
\hline
\end{tabular}

The dotted line joining the " $\mathrm{S}$ " and the $\mathrm{SO}_{4}^{2-}$ summit represents the typical tropospheric process of sea-salt aerosol scavenging by the atmospheric $\mathrm{H}_{2} \mathrm{SO}_{4}$, leading to the liberation of volatile $\mathrm{HCl}$ into the atmosphere (Legrand and Delmas, 1984). The area between the " $\mathrm{S}$ " and the $\mathrm{SO}_{4}$ summit also suggests that the composition of sea-salt is modified by the chloride depletion reactions with $\mathrm{Cl}^{-}$loss or gain, represented below or above the line, respectively. The snow samples beyond $50 \mathrm{~km}$ inland showed typical chloride depletion signatures, owing to the $\mathrm{H}_{2} \mathrm{SO}_{4}$ fluctuations in the atmosphere (Fig. 5b and c) with samples from the summer period closer to the $\mathrm{SO}_{4}$ summit, indicating predominant $\mathrm{H}_{2} \mathrm{SO}_{4}$ scavenging. However, the ternary plot representing samples from the steep faces of the escarpment $(\sim 1100 \mathrm{~m}$ altitude) showed strong fractionation of sea-salt, resulting in compositions enriched with $\mathrm{Na}^{+}$at specific segments between $20 \mathrm{~km}$ and $50 \mathrm{~km}$ (Fig. 5a). This plot also reveals a strong depletion of $\mathrm{Cl}^{-}$and $\mathrm{SO}_{4}^{2-}$ in samples specifically from $23 \mathrm{~km}, 26 \mathrm{~km}$ and $45 \mathrm{~km}$ (pink, green and red circles, Fig. 5a). At $30 \mathrm{~km}$ (maroon circles), the snow samples showed a cyclic variation with respect to $\mathrm{SO}_{4}^{2-}$ summit $\left(\mathrm{H}_{2} \mathrm{SO}_{4}\right.$ scavenging), along with a constant fractionation of $\mathrm{Cl}^{-}$with respect to $\mathrm{Na}^{+}$.

Even though variations in slope of the Antarctic ice sheet surface are known to cause significant impact on the wind processes and the snow accumulation rates, its impact on snow chemistry variations are the least studied. Frezzotti et al. (2002) have shown that even the smallest changes on the surface slope $\left(\sim 4 \mathrm{~m} \mathrm{~km}^{-1}\right)$ had a strong impact on the wind speed and direction. Richardson-Näslund (2004) had linked the large spatial variations in snow accumulation rates and the impact of katabatic winds, a unique wind system in the coastal Antarctica. The katabatic winds are remarkably uniform and the strongest of these winds are known to occur in the steep coastal sections of Antarctica (King and Turner, 1997). They are typically under-saturated in sea-salt aerosol as it blows from the higher inland plateau towards the coast (Wendler et al., 1993) and occur in the lowermost tens or few hundreds of meters (Barry, 2008; Argentini et al., 1996) above the surface. However, the influence of the surrounding ocean occurs on a much larger scale, enveloping the coastal region with warm, sea-salt rich and moist air mass.

The convergence of two opposing air masses with distinct temperature and moisture characteristics could result in a localized frontal wedging, especially over the steep coastal escarpments. Depending on the meteorological conditions, the sea-salt aerosols could either be scavenged by the precipitation and wet deposited or directly dry deposited over the snow surface. High annual accumulation rates with an average of $270 \mathrm{~kg} \mathrm{~m}^{-2} \mathrm{yr}^{-1}$ between the coast and $50 \mathrm{~km}$ suggests that the large amounts of sea-salt aerosols could be washed out of the atmosphere by the precipitating snow. Also, the sea-salt aerosols are known to be hygroscopic and are deliquesced at high relative humidity conditions $(60 \%-$ $70 \%$ ) before depositing on the snow surface. Studies by Ma et al. (2010) showed that high relative humidity conditions $(60 \%-80 \%)$ existed in the steep escarpment region of Princess Elizabeth Land. Alternatively, when conditions do not favour precipitation, the marine air mass rich in seasalt aerosols could be intercepted by the steep faces of the escarpment, which would result in turbulence-induced dry deposition of sea-salt particles. Thus, relatively high $\mathrm{Na}^{+}$ and $\mathrm{Cl}^{-}$concentrations over the steep faces of the coastal escarpment (Fig. 3) could be due to the preferential wet or dry deposition of sea-salt aerosols by the above deposition mechanisms. However, concentrations of $\mathrm{Na}^{+}$exceeded (up to four times) the $\mathrm{Cl}^{-}$concentrations at specific locations $(23,26$ and $45 \mathrm{~km})$ in the steep escarpment throughout the 


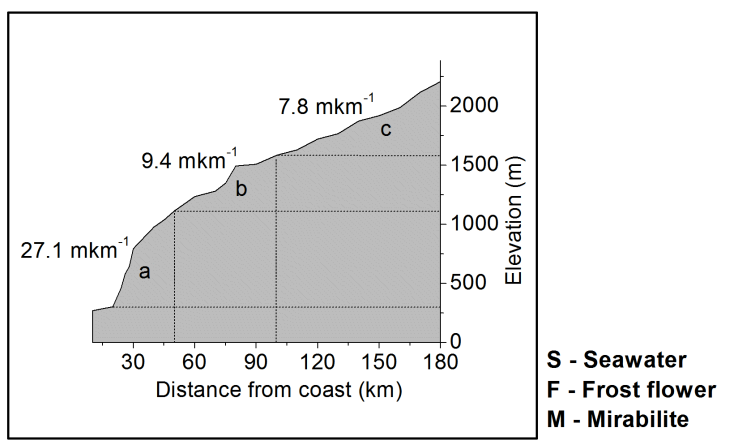

(b)

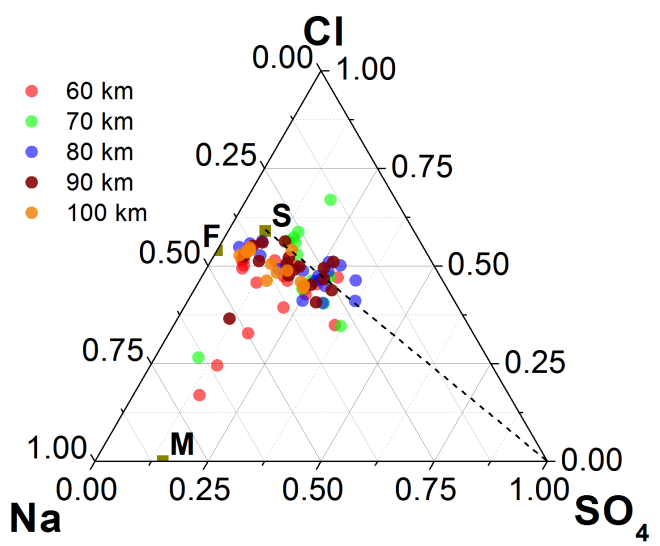

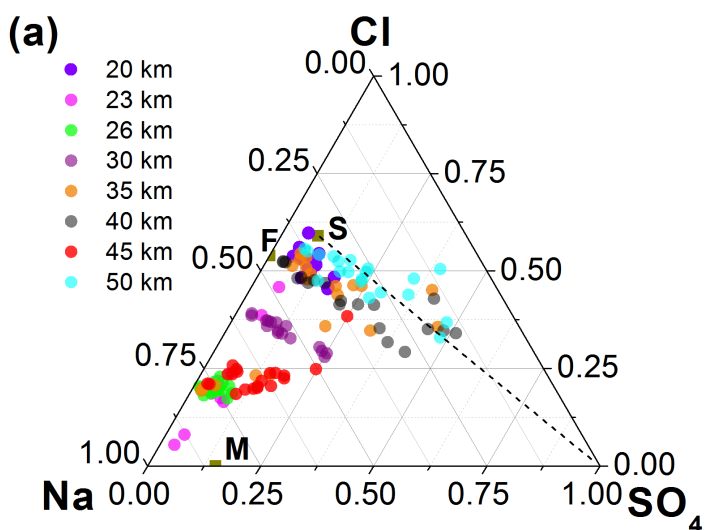

(c)

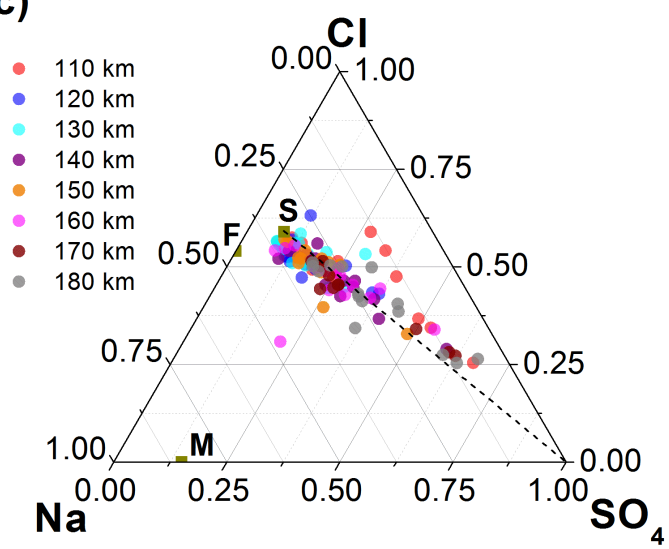

Fig. 5. Plot showing sea-salt modifications with respect to reference seawater (S) in snow samples from coastal (a), midway (b) and the interior (c) of the transect. Inset on the top left shows changes in the elevation and slope along the transect. See text for details.

year (Table 2). The variability of $\mathrm{Na}^{+}$concentration could be attributed to the wind induced redistribution of snow over the steep slopes, during which $\mathrm{Cl}^{-}$is lost due to its reaction with the atmospheric acids. Unlike $\mathrm{Cl}^{-}, \mathrm{Na}^{+}$does not undergo any reaction with the atmospheric acids, thereby getting accumulated (due to continuous sea-salt inputs) and redistributed (due to wind scouring). This fact is evidenced by a positive correlation $(0.590,95 \%$ significance $)$ existing between slope and only $\mathrm{Na}^{+}$concentration (since $\mathrm{Cl}^{-}$is lost during wind redistribution). The varying slope angles and the slope heights are known to affect the katabatic wind strengths (Frezzotti et al., 2002; Vihma et al., 2011) and we propose that the large differences in the slope variations of the coastal escarpment (Table 1) could significantly attribute to the wind redistribution and, in turn, the chemistry of deposited snow.

In the coastal part of Antarctica, most of the sea-salt aerosols are generated from the sea spray due to bubble bursting in the open ocean. However, studies have shown that during winter, a significant amount of sea-salt aerosols are generated from the frost flowers formed on the sea-ice surface (e.g. Wagenbach et al., 1998; Rankin et al., 2000). Sea-salt fractionation is apparent during the sea-ice formation, during which the highly saline brine or the frost flowers on the ice surface generate fractionated sea-salt aerosols. Multi-year sea ice data (Spreen et al., 2008) showed the presence of dominating sea-ice cover in the adjacent oceans of Princess Elizabeth Land for a major part of the year except summer (December-February). The ternary plot (Fig. 5a) reveals a strong depletion of $\mathrm{SO}_{4}^{2-}$ relative to the sea water, specifically at $23 \mathrm{~km}, 26 \mathrm{~km}$ and $45 \mathrm{~km}$ (pink, green and red circles, respectively). The strong depletion of $\mathrm{SO}_{4}^{2-}$ and $\mathrm{Na}^{+}$is associated with the aerosols generated from the brine after the precipitation of mirabilite $\left(\mathrm{Na}_{2} \mathrm{SO}_{4} \cdot 10 \mathrm{H}_{2} \mathrm{O}\right)$ below $-8^{\circ} \mathrm{C}$. The non-sea-salt $\mathrm{SO}_{4}^{2-}\left(\mathrm{nssSO}_{4}^{2-}\right)$ concentrations, calculated with $\mathrm{Na}^{+}$as the sea water reference species using the expression $\mathrm{nssSO}_{4}^{2-}=\left(\mathrm{SO}_{4}^{2-}\right)_{\text {snow }}-0.121\left(\mathrm{Na}^{+}\right)_{\text {snow }}$, showed negative values on the steep escarpments on the coast. The negative $\mathrm{nsSO}_{4}^{2-}$ generally implies a fractionated seasalt source originating from the frost flowers during winter conditions (e.g. Wagenbach et al., 1998; Rankin and Wolff, 2002). Negative nssSO ${ }_{4}^{2-}$ concentrations do not exist when the sea-salt aerosols are generated from the open ocean and when additional nssSO ${ }_{4}^{2-}$ from biogenic sources is added to the $\mathrm{SO}_{4}^{2-}$ in snow. However, in the present 
study, negative $\mathrm{nssSO}_{4}^{2-}$ existed throughout the year, including summer conditions. Wagenbach et al. (1998) associated the most negative nssSO $\mathrm{S}_{4}^{2-}$ with high sea-salt concentrations in coastal Antarctica, which tend to give an overestimated fractionation factor. High concentrations of $\mathrm{Na}^{+}$affected the $\mathrm{nsSSO}_{4}^{2-}$ calculations since the $\mathrm{nssSO}_{4}^{2-}$ value represents a small difference between two large numbers (Maupetit and Delmas, 1992). Therefore, the negative $\mathrm{nsSSO}_{4}^{2-}$ values are more likely attributed to the extremely high $\mathrm{Na}^{+}$concentrations (ranging between 100 and $1300 \mu \mathrm{gl}^{-1}$ ) in this region. When $\mathrm{nssSO}_{4}^{2-}$ was calculated using $\mathrm{Mg}^{2+}$ (since it precipitates below $-34{ }^{\circ} \mathrm{C}$ and occurs at much lower concentrations than $\mathrm{Na}^{+}$in sea water) as the sea water reference species, using the expression $\mathrm{nssSO}_{4}^{2-}=\left(\mathrm{SO}_{4}^{2-}\right)_{\text {snow }}-1.05\left(\mathrm{Mg}^{2+}\right)_{\text {snow }}$, the negative $\mathrm{nssSO}_{4}^{2-}$ values were present only in the winter snow.

\section{Conclusions}

The present study, using annual snow core records from the coast to inland transect in Princess Elizabeth Land, revealed significantly low $\mathrm{Cl}^{-} / \mathrm{Na}^{+}$ratios within $50 \mathrm{~km}$ from the coast. These sites are also characterized by a steep slope that decreases significantly inland. Strong correlation between slope and $\mathrm{Cl}^{-} / \mathrm{Na}^{+}$ratio suggests a predominant influence of slope on sea-salt chemistry of snow. Seasonal patterns revealed that $\mathrm{Cl}^{-}$concentrations were significantly lower than that of $\mathrm{Na}^{+}$on the steep zones throughout the year. The maritime air masses and the katabatic winds strongly interact in the coastal Antarctic regions, with the steep coastal slopes aiding in preferential deposition of seasalt aerosols in snow. The wind redistribution of snow, influenced by the slope variations increasing the $\mathrm{Na}^{+}$concentration, thereby lowers the $\mathrm{Cl}^{-} / \mathrm{Na}^{+}$ratios, and a possible overestimation of sea-salt fractionation along the steep slopes. We propose that higher concentrations of $\mathrm{Na}^{+}$with $\mathrm{Cl}^{-}$loss in snow are primarily driven by the steep slopes of coastal Antarctica. A combination of field measurements in snow and the aerosol would reveal more insight into this mechanism on the coastal regions across Antarctica.

Acknowledgements. We thank the Director, National Centre for Antarctic and Ocean Research for his encouragement and Ministry of Earth Sciences for financial support. We also thank C. T. Achuthankutty, K. Satheesan and two anonymous reviewers for providing useful suggestions and improving the quality of the manuscript. We thank S. Karunakaran for his continuous support with the ArcGIS software and maps. We are grateful for the support from the members and crew of the 28th Indian Scientific Expedition to Antarctica. We thank Australian Antarctic Division for providing the 2008 wind data. This is NCAOR contribution number 09/2012.

Edited by: J. Moore

\section{References}

Allison, I.: Surface climate of the interior of the Lambert Glacier basin, Antarctica, from Automatic weather station data, Ann. Glaciol., 27, 515-520, 1998.

Argentini, S., Mastrantonio, G., Viola, A., Pettre, P., and Dargaud, G.: Sodar performance and preliminary results after one year of measurements at Adelie Land coast, east Antarctica, Bound.Lay. Meteorol., 81, 75-103, doi:10.1007/BF00119401, 1996.

Aristarain, A. and Delmas, R. J.: Snow chemistry measurements on James Ross Island (Antarctic Peninsula) showing sea-salt aerosol modifications, Atmos. Environ., 36, 765-772, 2002.

Barry, R. G.: Mountain Weather and Climate, Cambridge University Press, Cambridge, UK, 506 pp., 2008.

Benassai, S., Becagli, S., Gragnani, R., Magand, O., Proposito, M., Ilaria, F., Traversi, R., and Udisti, R.: Sea-spray deposition in Antarctic coastal and plateau areas from ITASE traverses, Ann. Glaciol., 41, 32-40, 2005.

Bertler, N., Mayewski, P. A., Aristarain, A., Barrett, P., Becagli, S., Bernardo, R., Bo, S., Cunde, X., Curran, M., Dahe, Q., Dixon, D., Ferron, F., Fisher, H., Frey, M., Frezzotti, M., Fundel, F., Genthon, C., Gragnani, R., Hamilton, G., Handley, M., Hong, S., Isaksson, E., Kang, J., Ren, J., Kamiyama, K., Kanamori, S., Kärkäs, E., Karlöf, L., Kaspari, S., Kreutz, K., Kurbatov, A., Meyerson, E., Ming, Y., Zhang, M., Motoyama, H., Mulvaney, R., Oerter, H., Osterberg, E., Proposito, M., Pyne, A., Ruth, U., Simões, J., Smith, B., Sneed, S., Teinilä, K., Traufetter, F., Uditsi, R., Virkkula, A., Watanabe, O., Williamson, B., Winthen, J.-G., Li, Y., Wolff, E. W., Li, Z., and Zielinski, A.: Snow chemistry across Antarctica, Ann. Glaciol., 41, 167-179, doi:10.3189/172756405781813320, 2005.

Frezzotti, M., Gandolfi, S., and Urbini, S.: Snow megadunes in Antarctica: Sedimentary structure and genesis, J. Geophys. Res., 107, 4344, doi:10.1029/2001jd000673, 2002.

Frezzotti, M., Pourchet, M., Flora, O., Gandolfi, S., Gay, M., Urbini, S., Vincent, C., Becagli, S., Gragnani, R., Proposito, M., Severi, M., Traversi, R., Udisti, R., and Fily, M.: Spatial and temporal variability of snow accumulation in East Antarctica from traverse data, J. Glaciol., 51, 113-124, doi:10.3189/172756505781829502, 2005.

Giovinetto, M. B., Waters, N. M., and Bentley, C. R.: Dependence of Antarctic surface mass balance on temperature, elevation and distance to open water, J. Geophys. Res., 95, 3517-3531, 1990.

Goodwin, I.: Snow accumulation and surface topography in the katabatic zone of Eastern Wilkes land, Antarctica, Antarct. Sci., 2, 235-242, 1990.

Hall, J. and Wolff, E. W.: Causes of seasonal and daily variations in aerosol sea-salt concentrations at a coastal Antarctic station, Science, 32, 3669-3677, 1998.

Hara, K., Osada, K., Kido, M., Hayashi, M., Matsunaga, K., Iwasaka, Y., Yamanouchi, T., Hashida, G., and Fukatsu, T.: Chemistry of sea-salt particles and inorganic halogen species in Antarctic regions: Compositional differences between coastal and inland stations, J. Geophys. Res., 109, D20208, doi:10.1029/2004jd004713, 2004.

Helsen, M. M., Wal, R. S. W. V. D., Broeke, M. R. V. D., As, D. V., Meijer, H. A. J., and Reijmer, C. H.: Oxygen isotope variability in snow from western Dronning Maud Land, Antarctica and its relation to temperature, Tellus B, 57, 423-435, 2005. 
Jourdain, B. and Legrand, M.: Year-round records of bulk and sizesegregated aerosol composition and $\mathrm{HCl}$ and $\mathrm{HNO}_{3}$ levels in the Dumont d'Urville (coastal Antarctica) atmosphere: Implications for sea-salt aerosol fractionation in the winter and summer, J. Geophys. Res., 107, 4645, doi:10.1029/2002JD002471, 2002.

Kerminen, V. M., Teinilä, K., and Hillamo, R.: Chemistry of seasalt particles in the summer Antarctic atmosphere, Atmos. Environ., 34, 2817-2825, 2000.

King, J. C. and Turner, J.: Antarctic Meteorology and Climatology, Cambridge University Press, Cambridge, 409 pp., 1997.

Kreutz, K. and Mayewski, P. A.: Spatial variability of Antarctic surface snow glaciochemistry: implications for palaeoatmospheric circulation reconstructions, Antarct Sci., 11, 105-118, 1999.

Legrand, M. and Delmas, R. J.: The ionic balance of Antarctic snow: a 10-year detailed record, Atmos. Environ., 18, 18671874, 1984.

Legrand, M. and Delmas, R. J.: Formation of $\mathrm{HCl}$ in the Antarctic atmosphere, J. Geophys. Res., 93, 7153-7168, 1988.

Ma, Y., Bian, L., Xiao, C., Allison, I., and Zhou, X.: Near surface climate of the traverse route from Zhongshan Station to Dome A, East Antarctica, Antarct. Sci., 22, 443-459, doi:10.1017/s0954102010000209, 2010.

Maupetit, F. and Delmas, R. J.: Chemical composition of falling snow at Dumont D’Urville, Antarctica, J. Atmos. Chem., 14, 3142, 1992.

Minikin, A., Legrand, M., Hall, J., Wagenbach, D., Kleefeld, C., Wolff, E., Pasteur, E. C., and Ducroz, F.: Sulfur-containing species (sulfate and methanesulfonate) in coastal Antarctic aerosol and precipitation, J. Geophys. Res., 103, 10975-10990, 1998.

Murphy, D. M., Anderson, J. R., Quinn, P. K., McInnes, L. M., Brechtel, F. J., Kreidenweis, S. M., Middlebrook, A. M., Posfai, M., Thomson, D. S., and Buseck, P. R.: Influence of sea-salt on aerosol radiative properties in the Southern Ocean marine boundary layer, Nature, 392, 62-65, 1998.

Naik, S. S., Meloth, T., Rajakumar, A., Souza, W. D., Laluraj, C. M., and Chaturvedi, A.: Influence of climatic teleconnections on the temporal isotopic variability as recorded as recorded in a firn core from the coastal Dronning Maud Land, East Antarctica, J. Earth Syst. Sci., 119, 41-49, 2010.

Rankin, A. M. and Wolff, E. W.: Frost flowers: Implications for tropospheric chemistry and ice core interpretation, J. Geophys. Res., 107, 4683, doi:10.1029/2002jd002492, 2002.

Rankin, A. M., Auld, V., and Wolff, E. W.: Frost flowers as a source of fractionated sea salt aerosol in the polar regions, Geophys. Res. Lett., 27, 3469-3472, 2000.

Richardson-Näslund, C.: Spatial characteristics of snow accumulation in Dronning Maud Land, Antarctica, Global Planet. Change, 42, 31-43, doi:10.1016/j.gloplacha.2003.11.009, 2004.
Röthlisberger, R., Mulvaney, R., Wolff, E., Hutterli, M., Bigler, M., De Angelis, M., Hansson, M., Steffensen, J. P., and Udisti, R.: Limited dechlorination of sea-salt aerosols during the last glacial period: Evidence from the European Project for Ice Coring in Antarctica (EPICA) Dome C ice core, J. Geophys Res., 108, 4526, doi:10.1029/2003jd003604, 2003.

Röthlisberger, R., Mudelsee, M., Bigler, M., de Angelis, M., Fischer, H., Hansson, M., Lambert, F., Masson-Delmotte, V., Sime, L., Udisti, R., and Wolff, E. W.: The Southern Hemisphere at glacial terminations: insights from the Dome C ice core, Clim. Past, 4, 345-356, doi:10.5194/cp-4-345-2008, 2008.

Spreen, G., Kaleschke, L., and Heygster, G.: AMSR-E ASI 6.25 km Sea Ice Concentration Data, V5.2, Institute of Oceanography, University of Hamburg, Germany, digital media, 2008.

Stenberg, M., Isaksson, E., Hansson, M., Karlén, W., Mayewski, P. A., Twickler, M. S., Whitelow, S. I., and Gundestrup, N.: Spatial variability of snow chemistry in western Dronning Maud Land, Antarctica, Ann. Glaciol., 27, 378-384, 1998.

Thamban, M., Laluraj, C. M., Mahalinganathan, K., Redkar, B. L., Naik, S. S., and Shrivastava, P. K.: Glaciochemistry of surface snow from the Ingrid Christensen Coast, East Antarctica, and its environmental implications, Antarct. Sci., 22, 435-441, doi:10.1017/s0954102010000155, 2010.

Traversi, R., Becagli, S., Castellano, E., Largiuni, O., Migliori, A., Severi, M., Frezzotti, M., and Udisti, R.: Spatial and temporal distribution of environmental markers from Coastal to Plateau areas in Antarctica by firn core chemical analysis, Int. J. Environ. An. Ch., 84, 457-470, doi:10.1080/03067310310001640393, 2004.

Vihma, T., Tuovinen, E., and Savijärvi, H.: Interaction of katabatic winds and near-surface temperatures in the Antarctic, J. Geophys. Res., 116, D21119, doi:10.1029/2010JD014917, 2011.

Wagenbach, D.: Chemical exchange between the atmosphere and polar snow, Coastal Antarctica: atmospheric chemical composition and atmospheric transport, edited by: Wolff, E. W. and Bales, R. C., NATO ASI Series, New York, 1996.

Wagenbach, D., Ducroz, F., Mulvaney, R., Keck, L., Minikin, A., Legrand, M., Hall, J., and Wolff, E.: Sea-salt aerosol in coastal Antarctic regions, J. Geophys. Res., 103, 10961-10974, 1998.

Wagnon, P., Delmas, R. J., and Legrand, M.: Loss of volatile acid species from upper firn layers at Vostok, Antarctica, J. Geophys. Res., 104, 3423-3431, 1999.

Wendler, G., André, J. C., Gosink, J., and Parish, T.: Katabatic winds in Adélie coast, in: Antarctic meteorology and climatology: studies based on automatic weather stations, edited by: Bromwich, D. H. and Stearns, C. R., 61, American Geophysical Union, Washington, 23-46, 1993. 